\title{
A guideline proposal to formulate an environmental policy for tourism in the Topocoro reservoir in Colombia
}

\section{Propuesta de lineamientos generales para la formulación de la política ambiental de turismo en el embalse Topocoro en Colombia}

\author{
Daniel Corzo-Arévalo ${ }^{1}$ \\ 1 Researcher Professor Comfenalco Santander University Foundation, Bucaramanga, Colombia. Master's student in Tourism Management, National University of Quilmes (Argentina).
} *Corresponding author dcorzoarevalo(quvq.edu.ar

\section{ABSTRACT}

Reservoirs may have the potential to develop tourist activity that benefits local communities, though this requires an environmental policy that allows and regulates their proper use and exploitation without affecting the territory's own elements on a large scale. This document identifies the main items that should form the environmental policy for tourism in the Topocoro reservoir, or any other reservoir with tourist potential. As a preamble to the study, a precise definition of sustainable tourism is offered, the challenges of generating an environmental policy for tourism in the face of the exploitation-preservation dichotomy are described, the importance of the state as a regulatory entity is emphasized, and finally some guidelines are established for the formulation of this environmental policy in the Sogamoso hydroelectric plant.

Keywords: Sustainable tourism, reservoirs, environmental policy, Topocoro, Hidrosogamoso.

\section{RESUMEN}

Los embalses pueden tener un potencial para desarrollar actividades turísticas que beneficien a las comunidades locales, pero esto requiere una política ambiental que permita y regule su buen uso y aprovechamiento sin afectar a gran escala los elementos propios del territorio. Este documento permite identificar los principales ítems que deberían conformar la política ambiental de turismo del embalse Topocoro, o de cualquier otro embalse con potencial turístico. Como preámbulo al estudio, se ofrece una definición precisa del turismo sostenible, se describen los retos de generar una política ambiental de turismo de cara a la dicotomía explotación-preservación que el turismo sostenible presenta, se enfatiza la importancia del estado como ente regulador cuya misión es integrar los intereses de la comunidad local, las empresas y los turistas, y finalmente se establecen unos lineamientos para la formulación de esta política ambiental en la hidroeléctrica Sogamoso.

Palabras clave: Turismo sostenible, embalses, política ambiental, Topocoro, Hidrosogamoso. 


\section{INTRODUCTION}

The growth of new segments of tourist demand that show a clear interest in natural and alternative attractions (Reguero Oxinalde, 1994) offers an opportunity to diversify with contemporary tourist products, especially those that link nature as their most valuable resource. In this context, the construction of dams has turned them into a destination for tourist activity. In recent years there has been growth in the tendency to use the waters of a reservoir for tourism, complementing other more traditional activities in the territory (García Gonzáles, 2004).

This growth should not be left to chance and must be treated with a sustainable growth approach. According to Fortunato (2019b), the opportunities for growth and development in contemporary tourist spaces require three elements: first, environmental public policy capable of satisfying the needs of current generations without compromising the needs of future generations; second, that professionals in the sector have the necessary knowledge to promote the tourist destination; third, effective public management (Fortunato, 2019b).

The Topocoro reservoir, located in the Sogamoso hydroelectric plant in the Santander department, Colombia, is not exempt from the growing influx of tourists. In the last few years, both supply and demand of tourism have increased. This is an indication of a notable possibility to gain an important positioning in the market for nature, nautical and rural tourism. The rising demand in the reservoir calls for creating instruments and optimizing means for guaranteeing the quality of the visit, both in terms of tourist satisfaction and preservation of the resources that conform its tourist value.

It should be noted that the main objects of attraction for the tourist influx are the elements of the natural scape. Then, even if only from a pure marketing perspective, the preservation of these elements should be a primary aspect to be considered by those who profit from tourism development (Pulido Fernández, 2007). It is therefore necessary to create a tourism policy that can guarantee the sustainable management of these spaces, as well as favor its competitive market positioning, to make them actual tourist sites.

That is why the aim of this paper is to plan some general guidelines for the construction of an environmental policy for tourism in the Topocoro reservoir. This policy should guide the posterior formulation of an integral tourism plan that ensures its proper tourist use and profiting, without affecting the ability of new generations to also profit from it.

In order reach this goal, a theoretical analysis of sustainable tourism, environmental policy for tourism and reservoir tourism as a source of local development is made. A contextualization of the case study is provided, following a methodical process in three phases. The first phase is diagnosis, in which the territory is deeply examined from an environmental and socioeconomic perspective (López, 1998). The second phase is a comparative analysis of several reservoirs with tourist activity, used as a source for the Competitive Profile Matrix (CMP). Finally, guidelines are formulated for the environmental policy for tourism.

Why create an environmental policy for tourism in a reservoir? Reservoirs have potential to develop tourist activities that benefit local communities, but they must have an environmental policy that allows for and regulates its use and exploitation without greatly affecting the original features of the territory.

The construction of the Topocoro reservoir has transformed the productive activity of its influence zone, affecting the social dynamics in the region, generating new productive activities and posing new challenges for environmental conservation. In some occasions the environmental patrimony can be particularly vulnerable to human activity, starting a degradation process that can irreversibly damage the very elements on which tourism depends (Kobal, 2002).

The Reservoir Regulation Plan (RRP) for Topocoro contemplates some alternative uses, among which is nature tourism and a few sub products such as rural tourism, cultural tourism and scientific tourism. Considering that the RRP dedicates $25 \%$ of the reservoir area for productive development of this kind, it is indispensable to set some tools that allow for caring and preservation of the territory's endogenous elements.

Environmental patrimony as a resource for tourism is comprised of a series of elements that need to be protected from any activity that can degrade it (Kobal, 2002). It is inconceivable today to think of tourism development in 
a way that does not guarantee the quality and quantity of natural and cultural resources. Tourism must be sustainable, even more so for reservoirs which, besides covering their inherent needs such as electricity production, irrigation and flood control, must also function as tourist sites, contributing to economic progress in the region (Díaz, Castaño \& Navarrete, 2016).

It is hence necessary to establish, primarily from public management, guidelines for an environmental policy for tourism. This policy should facilitate adequate and sustainable management of the environment, preservation and protection of the natural and cultural diversity and implementation of sustainable development in the territory. Also, it should be organized in terms of objectives, fundamental principles and tools for management and evaluation.

\section{THEORETICAL FRAMEWORK Towards a definition of sustainable development}

Fortunato (2019c) offers a recount of how the term "sustainable development" was coined in the report by the World Commission on Environment and Development, sponsored by the United Nations. The 1987 report defined sustainable development as a development model capable of satisfying the needs of present generations without compromising the needs of future generations (Fortunato, 2019c). Being tourism an economic activity of vital importance for the Latin American region, it is imperative to evaluate its role in the equation for sustainable development.

The term "sustainable tourism" shall be used to refer to tourism in the context of sustainable development. It should be noted that, since the term does not have a formal definition, it can evoke up to four different connotations: "economic sustainability of tourism, ecologically sustainable tourism, sustainable tourism development in the long term, and tourism as part of a sustainable development strategy" (Coccossis, 1996). However, in this study we will focus exclusively on the second definition, which extends sustainable tourism as tourism that grows in time while ensuring the conservation of the environment for future generations.

In this context, Bertoni (2008) provides a deep characterization of (ecologically) sustainable tourism. In her pers- pective, truly sustainable tourism does not exclude the sustainability of the human system nor the ecological system, but rather integrates both (Bertoni, 2008). Sustainable tourism thus adopts a socioecological approach, seeking long term conservation of the communities and the environment in one symbiotic system, safeguarding and nurturing the relations between human beings and nature. Socioecologically sustainable tourism activity is therefore renamed as ecotourism, which implies travelling to or visiting natural spaces to appreciate the natural and cultural attractions that inhabit them, without hindering but rather contributing to the development of local settlers (Bertoni, 2008).

\section{Policy for sustainable tourism}

Adopting the aforementioned definition of sustainable tourism with a socioecological approach poses multiple challenges. First, the concept of sustainability itself is problematic: even if there is consensus that it should be a social goal, when it comes to deciding how to achieve it, conflict tends to arise between stakeholders as each one defends their own interest (Bertoni, 2008). The root of the problem is the dichotomy-inevitably created by sustainable development - between exploitation of the natural area as a tourism resource and its concurrent conservation. The utilitarian perspective of nature contrasts sharply with the goal of preserving the ecosystem and improving the life conditions of local communities (Bertoni, 2008).

The exploitation-preservation dichotomy does not allow for sustainable tourism to arise as a natural, spontaneous state of the tourist space. In order to achieve sustainable tourism, a regulatory entity will have to intervene by creating, implementing and enforcing a policy that makes it possible. This process will need the political will to adapt, with the involvement of the local community, the institutional and legal framework, as well as the planning and management tools (Vera-Rebollo, 2001). In sum, sustainable tourism needs a permanent flow and management of resources, dialogues and relationships between stakeholders.

Although several methods and processes for creating sustainable tourism policy have been created, the literature agrees that the fundamental element is the priority focus on the local communities' interests and the environmental conservation of the tourist space. Bertoni (2008) expresses: "for an effective development of sustainable tourism, the main issue is to identify social needs. It is important to 
consider not only the impact of tourism, carrying capacity and modality of the tourist activity, but also the institutional capacity of the region and its development style."

This focus on the local community reveals the tight relationship between sustainable tourism and territorial tourism. In turn, this relationship exposes the need for the sustainable tourism policy of a territory to be included into its development plan, so that it is measured by social, cultural and environmental progress of its communities (Ávila \& Barrado, 2005). Ávila \& Barrado (2005) picture sustainable tourism integrated into territorial development, for whose planning it is necessary to consider multiple factors such as life quality, productive structure, the degree of associativity, the installation of decision making and management formulas that are somewhat agreed upon and the nature of other economic sectors. These issues are summarized in their strategic framework for integral planning of tourist destinations, illustrated below.

Figure 1. Strategic framework for integral planning of tourist destinations

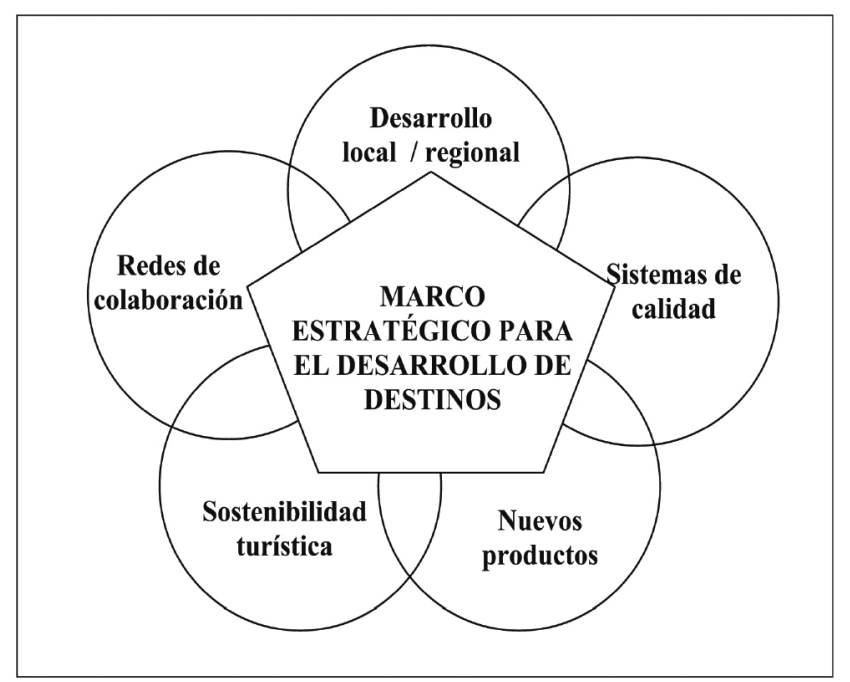

Source: Ávila \& Barrado (2005)

\section{Reservoir tourism as a source of local development}

Reservoirs, being human-made structures, have become important tourism resources in multiple places. In particular, countries such as Colombia that are favored with a great amount of water resources tend to adopt policies for exploiting them, turning reservoirs into new sources of social and economic phenomena. One of these is the fact that reservoirs become important tourist sites.

Swyngedouw (2009) argues for the perspective of the hydro-social context, in which water circulation is a process that combines the physical (or geographical) and the social. A reservoir is a hybrid socionatural flux, combining nature and society-the same symbiotic system observed by Bertoni (2008). Society thus territorializes, giving a character of social production to the territory itself (Porto-Goncalves, 2009).

From the perspective of sustainable tourism integrated with territorial development, a good tourism policy should mainly defend the interests of the local communities and safeguard their environment. At the same time, it should allow for the tourism resource to be exploited, producing economic benefits.

However, the exploitation-preservation dichotomy makes this difficult to realize. For instance, Roa (2019) warns about the conflicts of interest between the local community of the Sogamoso region, where the Topocoro reservoir is located, and the landowners who own large enterprises. Soon after construction was finished, these business owners founded the Corporation for Sustainable Development in the Hidrosogamoso Influence Zone (Corsogamoso) and associated with the two largest family welfare funds in Santander to promote tourism in the region (Roa, 2019). While the landowners saw their lands and businesses' value increase - their hotels, restaurants and guided tours around the lake were booming-the local settlers were struggling to sustain their microenterprises for community tourism (Roa, 2019).

Although the RRP that was later established made it possible to even out the ground by including the local community's participation in its formulation, it is undeniable that the local community started in a disadvantaged position. Even worse, it was they who suffered the immediate consequences of the construction of the reservoir in their vicinity. Just to name a few, they had to deal with polluted water being poured into the rivers, mass death of fish and other flora and fauna, and the fact that the reservoir drew an immense dividing line between communities that were previously neighbors (Roa, 2019). 
An adequate policy for sustainable tourism or an environmental policy for tourism should be capable of anticipating and mitigating these social inequalities and asymmetries, preventing the hegemonic groups from capturing all the benefits of tourism with no regard for the consequences for the local community and environment-something that Roa (2019) calls "hydrocracy". It is possible that all stakeholders (community, business, tourists) profit from reservoir tourism if the regulating entity promotes and manages a sustainable socioecological approach. It is important that the public opinion be aware of the environmental issues, safeguarding the value of natural resources and the differentiated consumption of non-deteriorated natural spaces (Bertoni, 2008).

\section{METHOD}

\section{Type of study}

This paper is based on descriptive and interpretative research. Its main objective is to describe tourism phenomena from observing reality in a given period. Three phases were determined to understand the context in which tourist and recreational activity is developed in the Topocoro reservoir, as well as to compare various reservoirs with tourist potential in Colombia. Finally, some guidelines were established for an environmental or sustainability for the enjoyment, profiting, caring and conservation of the natural and cultural patrimony.

Throughout each phase, a document analysis was made with the aim of creating certain criteria that would provide a general panorama of the impact of the Topocoro reservoir on a social and environmental level. The document analysis was developed in five steps: i) revision of available literature, ii) document classification, iii) selection of relevant sources, iv) reading and analysis to extract the critical elements, v) comparative cross-analysis, focusing on the critical elements previously found.

Figure 2. Method in three steps

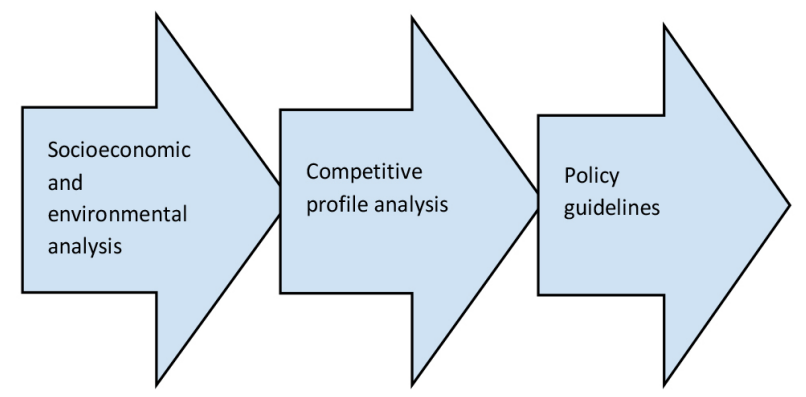

The socioeconomic analysis allows to examine the generalities of the Topocoro reservoir, as well as its conflicts with regard to land ownership, benefit distribution to communities and use of the land in its influence zone. The competitive profile analysis was based on the competitive profile matrix, setting five critical success factors for the development of nature tourism products in reservoirs with tourist potential. Lastly, guidelines for an environmental policy are suggested based on the framework by Pulido (2017), which will be used as a resource for regulating touristic activity in this territorial unit.

\section{Results \\ Socioeconomic Analysis}

Every planning process for a resource demands knowing its initial state as the first step (Ávila \& Barrado, 2005). Hence, an inventory of the relevant elements for facilitating the tourist exploitation of the Topocoro reservoir in the context of its integral use is required. This inventory will tell what the components of highest value are, indicating its potential. It is also important to anticipate the possible issues that affect these elements so tourism can develop in a way that contributes to the development of the surrounding communities.

Generalities: the hydroelectric project of the Sogamoso river, named Topocoro reservoir, was carried out by the mixed capital enterprise ISAGÉN S.A. E.S.P, whose stocks are distributed as follows: $57.66 \%$ for the state, $12.95 \%$ for public enterprises in Medellín EPM, 14.95\% for companies managing pension funds and $14.46 \%$ for small stockholders.

The Sogamoso Hydroelectric Project is located in the department of Santander, in the canyon where the Sogamoso river crosses the La Paz mountain range, $75 \mathrm{~km}$ upstream of the Magdalena river estuary and $62 \mathrm{~km}$ upstream of the confluence of the rivers Suarez and Chicamocha. It is one of the five largest power plants in the country, representing $50 \%$ of the consumption of a city like Bogotá, which is $10 \%$ of the energy that the whole of Colombia consumes in one year.

Its influence zone comprises of the Santander towns of Betulia, San Vicente de Chucurí, Zapatoca, Lebrija, Girón and Los Santos (Plata \& Carlos, 2017). However, its local influence zona is located in the following villages: 
Table 1. Influence zone of the Topocoro reservoir by town

\begin{tabular}{|c|c|c|c|}
\hline TOWN & PERIMETER KM & $\begin{array}{c}\text { AREA IN } \\
\text { HECTARES }\end{array}$ & VILLAGES \\
\hline Betulia & 75,6 & 3.458 & $\begin{array}{l}\text { Chimita, Balzora, } \\
\text { El Placer, } \\
\text { Sogamoso, El } \\
\text { Tablazo, San } \\
\text { Mateo, Putana. }\end{array}$ \\
\hline $\begin{array}{l}\text { San Juan de } \\
\text { Girón }\end{array}$ & 64,5 & 2.856 & $\begin{array}{l}\text { Sogamoso, } \\
\text { Chocoa, Cantalta, } \\
\text { Cantalta- } \\
\text { Guaimaral, El } \\
\text { Pantano, Motoso, } \\
\text { La Parroquia. }\end{array}$ \\
\hline Zapatoca & 49 & 767 & $\begin{array}{l}\text { Belmonte, La } \\
\text { Plazuela, La } \\
\text { Plazuela - } \\
\text { Miraflores, } \\
\text { Chocoa, San Isidro }\end{array}$ \\
\hline Los Santos & 18,71 & 139 & $\begin{array}{l}\text { La Loma, } \\
\text { Regadero Bajo, } \\
\text { Espiral Bajo, } \\
\text { Llanadas, Purnia } \\
\text { Nueva. }\end{array}$ \\
\hline $\begin{array}{l}\text { San Vicente } \\
\text { de Cuchurí }\end{array}$ & 11,6 & 182 & $\begin{array}{l}\text { Cantarrana, La } \\
\text { Esperanza, } \\
\text { Cantarrana } 1 \text { y 2, } \\
\text { Los Medios, } \\
\text { Guayacán, La } \\
\text { Lizama II. }\end{array}$ \\
\hline Lebrija & 1 & 3,7 & La Renta, Lisboa. \\
\hline
\end{tabular}

Source: García (2017)

\section{Environmental Analysis}

The problem in most hydropower plants around the world lies in their ineffective planning (Ansar, Flyvbjerg, Budzier \& Lunn, 2014). The social and environmental effects of the construction of large dams are not given enough im- portance, incurring additional costs due to delays in construction and mitigation plans. Some causes for the cost overrun after construction are protests, relocations, reforesting, ecosystem recovery, inclusion of affected native species, among others (Jaramillo, 2018).

The projects built in Colombia, and those currently in construction, have already undergone pressure from multiple social and environmental demands. However, the companies that run those projects argue that the environmental impact is due to factors beyond the construction, as is the case of the Hidrosogamoso reservoir (Roa \& Duarte, 2012). It should be considered that these companies have action plans regarding the issues caused by their projects; however, those actions fall short of the needs of the affected communities and the environment.

Therefore, the main instrument for planning the territorial unit is the Reservoir Regulation Plan (RRP), which in the case of Topocoro determines some primary and secondary uses that would allow to reduce the environmental impact during ongoing operation.

Table 2. Primary and secondary uses of the Topocoro reservoir

\begin{tabular}{|c|l|}
\hline Primary & $\begin{array}{l}\text { Power generation and presrvation of the } \\
\text { biodiversity }\end{array}$ \\
\hline Secondary & $\begin{array}{l}\text { Subsistence fishing, traditional fishing, water } \\
\text { transport, recreation and nature tourism, } \\
\text { water sports, water for consumption, } \\
\text { agricultural activity }\end{array}$ \\
\hline Conditional & Recreational fishing, jet skiing \\
\hline Not & Aquaculture, swimming, diving, hunting \\
\hline
\end{tabular}

Source: Fuentes \& Prada (2017)

Despite there being clear norms that regulate the Topocoro reservoir, several problems have been created around it. Some of the gravest ones are the overflow and the bad odor it emits (Díaz, Castaño \& Navarrete, 2016).

"A technical failure in one of the Sogamoso reservoir gates 
caused the flow of the river to reduce up to $70 \%$ when the reservoir filling process began. The situation took the nearly 1,500 farmers living by the La Playa sector by surprise. In Barrancabermeja (Santander), people that went fishing in the early morning found a dry river. For ten hours, the fishermen blocked the road that connects Barrancabermeja to Bucaramanga." (Díaz, Castaño \& Navarrete, 2016).

Isagén, the company that built the dam, provided a few solutions to the farmers. They agreed to compensate the affected families, to identify production projects that could be implemented with the community and to visit the land upstream from the reservoir in order to start some tourist projects. In 2015, the Administrative Tribunal of Santander ordered Isagén to clean the vegetation covering the water body and to remove all soft and organic material from the Sogamoso river, as well as to take some preventive measures. The decision followed a lawsuit by the local settlers, who complained about the bad odors and the loss of water quality. They even reported suffering from health issues such as nausea, vomiting, headaches and skin problems.

The impact of tourist activity on the environment depends mainly on the following aspects: modality of the resource use, intensity of resource use, intrinsic fragility of the resource and tourist conduct (Melgosa, 1999). Hence, the use of each area of the reservoir must be previously evaluated so as to mitigate the negative impact of the aforementioned aspects.
Table 3. Use of the Topocoro reservoir

\begin{tabular}{lrr} 
USE & HECTARES & PERCENTAGE \\
Fishing area & $3.211,5$ & $56,1 \%$ \\
Nature tourism & $1.460,5$ & $25,5 \%$ \\
Water sports & 419,5 & $7,3 \%$ \\
Recreation area & 405,4 & $7,1 \%$ \\
Fishing restriction & 195,3 & $3,4 \%$ \\
Operation area & 31,6 & $0,5 \%$ \\
Anchoring area & 0,3 & $0,01 \%$ \\
Level 300 masl & $5.724,1$ & 100 \\
\hline
\end{tabular}

Source: Isagén (2015)

As outlined in Table 3, nature tourism corresponds to $25.5 \%$ of the reservoir's total area, though complementary tourist activities should also be considered: that is $7.1 \%$ for recreation and $7.3 \%$ for water sports. This means that a total of $39.9 \%$ of the reservoir area should be reserved for tourist activities, which implies some strong bargaining power in political negotiations when creating policy for tourism in the reservoir.

Since more than a third of the Topocoro reservoir is dedicated to tourism and complementary tourist activities, it is worth mentioning that tourism too generates environmental issues. These should be taken into account

Table 4. Environmental issues generated by tourism

\begin{tabular}{|c|c|c|}
\hline TOURISM STAGE & ENVIRONMENTAL ISSUES & ENVIRONMENTAL IMPACT \\
\hline \multirow{5}{*}{$\begin{array}{l}\text { TRANSPORTATION } \\
\text { CYCLE }\end{array}$} & Use of valuable land for infrastructure & \multirow{2}{*}{ Consumption of scarce renewable resources } \\
\hline & Impact of infrastructure on nature & \\
\hline & Fuel consumption for transportation & \multirow[b]{2}{*}{ Consumption of scarce non-renewable resources } \\
\hline & $\begin{array}{l}\text { Use of material and financial resources for } \\
\text { infrastructure }\end{array}$ & \\
\hline & Emissions produced by transportation (CO2, SO2, etc.) & Emissions with large effects on key global issues \\
\hline \multirow{7}{*}{ STAY CYCLE } & Use of valuable land for tourist activities & \multirow[b]{2}{*}{$\begin{array}{l}\text { Consumption of scarce and valuable cultural } \\
\text { resources and renewable natural resources }\end{array}$} \\
\hline & $\begin{array}{l}\text { Pressure on the natural and cultural patrimony } \\
\text { Mutation of the physical environment and the } \\
\text { landscape (ecosystem crisis, desertification, bush fires) } \\
\text { Impact on the hydric system } \\
\text { Impact on the human system }\end{array}$ & \\
\hline & Fuel consumption for local transportation & \multirow{2}{*}{$\begin{array}{l}\text { Consumption of non-renewable resources and } \\
\text { financial resources }\end{array}$} \\
\hline & $\begin{array}{l}\text { Use of material and financial resources for } \\
\text { infrastructure and tourist equipment }\end{array}$ & \\
\hline & Polluting emissions in the air & \multirow{3}{*}{ Polluting emissions } \\
\hline & Polluting emissions in the water & \\
\hline & Noise pollution & \\
\hline
\end{tabular}

Source: Vera \& Marchena (1996) 
when setting guidelines to regulate tourist activity in the reservoir.

\section{Competitive Analysis}

The direct competitiveness of the Topocoro reservoir was evaluated by considering characteristics such as flora and fauna, environmental factors such as weather, temperature, orography and hydrography. Similarities were determined through the competitive profile matrix, developed by David (2003).

The competitive profile matrix (CPM) is a tool for comparing key conditions or factors in the market segment of a company or tourist site. It allows to calculate a weighted score that indicates the state that a tourist site is in. Weights are assigned according to the analyst's perspective. Factors that are considered more important are given a higher weight, though the weight of any given factor must not be greater than 1 (100\%). The score for each factor goes from 1 to 4,1 meaning that the site is not represented by that factor and 4 meaning that the site is perfectly represented by that factor.

The analysis for the present study is made from a sustainability perspective, highlighting the environmental, social and economic aspects of the Guavio, Tominé, Guatapé and Topocoro reservoirs. Each reservoir is analyzed based on some critical success factors for nature tourism, in order to evaluate their competitiveness. By convention, " $\mathrm{S}$ " stands for score and "WS" stands for weighted score in the competitive profile matrix.
Guavio Reservoir: located in the town of Gachalá, in the Cundinamarca department.

Tominé Reservoir: covers land belonging to the Guatavita and Sesquilé towns, located north of Bogotá city.

Guatapé Reservoir: located in eastern Antioquia. Its construction required the demolition of the town of El Peñol, inclusing several rural houses in El Peñol and Guatapé.

In the environmental aspect, the Guavio, Tominé and Guatapé reservoirs show great pollution due to poor management of solid and liquid waste, as well as issues related to the stillness of water. In most reservoirs the natural ground ecosystem is badly affected, as it is covered by vegetation which eliminates the local flora and fauna and forces them to relocate.

Another important environmental factor is the flood risk in downstream sectors of the river, whether it be due to exceeding its own limits or due to natural or artificial disasters. Also, greenhouse gas levels are altered since the natural vegetation in riverbanks is replaced by large water bodies, which can heat up and generate methane and $\mathrm{CO} 2$, thus contributing to climate change.

Reservoirs impede the natural flow of water, accumulating sediment, nutrients and organisms which generate pollution due to toxic substances. That is the case of the Guatapé reservoir, whose water turned green due to the proliferation of algae. 
Table 5. Environmental issues generated by tourism

\begin{tabular}{|c|c|c|c|c|c|c|c|c|c|c|}
\hline \multirow{2}{*}{ Dimension } & \multicolumn{2}{|c|}{ RESERVOIRS WITH TOURIST POTENTIAL } & \multicolumn{2}{|c|}{ Topocoro } & \multicolumn{2}{|c|}{ Guavio } & \multicolumn{2}{|c|}{ Tominé } & \multicolumn{2}{|c|}{ Guatapé } \\
\hline & Critical success factors & Weight & $\mathbf{S}$ & WS & $\mathbf{S}$ & WS & $\mathbf{S}$ & WS & $\mathbf{S}$ & WS \\
\hline \multirow{6}{*}{ 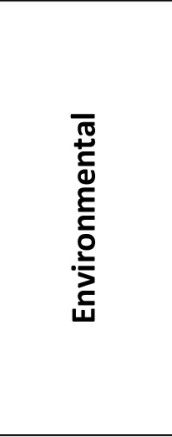 } & Variety of natural resources & 0,1 & 4 & 0,4 & 4 & 0,4 & 4 & 0,4 & 3 & 0,3 \\
\hline & $\begin{array}{l}\text { Adequate management of solid } \\
\text { and liquid waste }\end{array}$ & 0,2 & 2 & 0,4 & 1 & 0,2 & 1 & 0,2 & 1 & 0,2 \\
\hline & $\begin{array}{l}\text { Preservation and care of native } \\
\text { flora and fauna }\end{array}$ & 0,3 & 1 & 0,3 & 2 & 0,6 & 2 & 0,6 & 2 & 0,6 \\
\hline & $\begin{array}{l}\text { Has an environmental policy for } \\
\text { tourism }\end{array}$ & 0,1 & 1 & 0,1 & 2 & 0,2 & 3 & 0,3 & 4 & 0,4 \\
\hline & $\begin{array}{l}\text { Has areas of tourist, ecological or } \\
\text { scientific interest }\end{array}$ & 0,2 & 2 & 0,2 & 2 & 0,2 & 2 & 0,2 & 4 & 0,4 \\
\hline & Tourist carrying capacity & 0,1 & 1 & 0,1 & 2 & 0,2 & 2 & 0,2 & 3 & 0,3 \\
\hline \multicolumn{2}{|c|}{ Total environmental score } & 1,0 & & 1,5 & & 1,8 & & 1,9 & & 2,2 \\
\hline \multirow{6}{*}{ 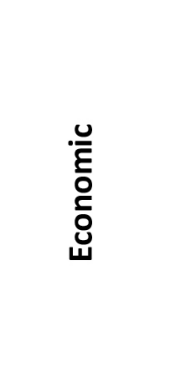 } & Corporate investment & 0,1 & 3 & 0,3 & 2 & 0,2 & 1 & 0,1 & 4 & 0,4 \\
\hline & $\begin{array}{l}\text { Economic return for local } \\
\text { communities }\end{array}$ & 0,3 & 1 & 0,3 & 1 & 0,3 & 2 & 0,6 & 3 & 0,9 \\
\hline & $\begin{array}{l}\text { Geographical proximity to a } \\
\text { capital city }\end{array}$ & 0,1 & 3 & 0,3 & 4 & 0,4 & 2 & 0,2 & 3 & 0,3 \\
\hline & Changes in land use & 0,1 & 2 & 0,2 & 3 & 0,3 & 3 & 0,3 & 3 & 0,3 \\
\hline & Formal employment & 0,2 & 1 & 0,2 & 3 & 0,6 & 2 & 0,4 & 3 & 0,6 \\
\hline & $\begin{array}{l}\text { Complementary activities for } \\
\text { tourism }\end{array}$ & 0,2 & 2 & 0,4 & 3 & 0,6 & 3 & 0,6 & 1 & 0,2 \\
\hline \multicolumn{2}{|r|}{ Total economic score } & 1,0 & & 1,7 & & 2,4 & & 2,2 & & 2,7 \\
\hline \multirow{6}{*}{ 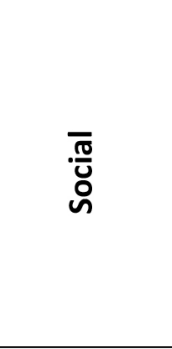 } & $\begin{array}{l}\text { Basic services coverage (piping, } \\
\text { sewage, waste disposal, gas) }\end{array}$ & 0,3 & 2 & 0,6 & 4 & 1,2 & 3 & 0,9 & 4 & 1,2 \\
\hline & Roads & 0,2 & 4 & 0,8 & 3 & 0,6 & 2 & 0,4 & 3 & 0,6 \\
\hline & Emigration of local communities & 0,1 & 2 & 0,2 & 2 & 0,2 & 1 & 0,1 & 3 & 0,3 \\
\hline & $\begin{array}{l}\text { Preservation and promotion of } \\
\text { local culture }\end{array}$ & 0,2 & 2 & 0,4 & 2 & 0,4 & 2 & 0,4 & 4 & 0,8 \\
\hline & Unsatisfied basic needs index & 0,1 & 2 & 0,2 & 3 & 0,3 & 3 & 0,3 & 3 & 0,3 \\
\hline & Development of nearby towns & 0,1 & 2 & 0,2 & 3 & 0,3 & 2 & 0,2 & 1 & 0,1 \\
\hline \multicolumn{2}{|r|}{ Total social score } & 1,0 & \multicolumn{2}{|r|}{2,4} & \multicolumn{2}{|r|}{3,0} & \multicolumn{2}{|r|}{2,3} & \multicolumn{2}{|r|}{3,3} \\
\hline \multicolumn{2}{|r|}{ TOTAL SCORE } & 3 & \multicolumn{2}{|r|}{5,6} & \multicolumn{2}{|r|}{7,2} & \multicolumn{2}{|r|}{6,4} & \multicolumn{2}{|r|}{8,2} \\
\hline
\end{tabular}

Farmer relocation during the filling process of reservoirs causes them to create new agricultural exploitation patterns in their new residence areas. Also, some studies have found a correlation between reservoir filling and seismic activity.

With regard to the economic dimension, the original production dynamics of the land change abruptly even before construction begins. Most economic activity turns towards tourism. Dam construction generates great speculation in land prices; land stops being productive to turn into recreation areas where tourism can flourish.

Food capacity in the region can be affected in the long term, given that agriculture and fishing patterns are altered. Informal commerce may increase as surrounding areas make a turn towards tourism. Critical changes in the economy may force local settlers to relocate due to price changes for staple products, generating migration waves to other cities.

\section{Guidelines for an Environmental Policy for Tourism}

This document posits that the territorial government in 
the Santander department, as the articulator of six municipalities, should play a proactive role in the development of tourism in the influence zone of the Topocoro reservoir. This role should be oriented towards: i) emphasizing aspects or correcting mistakes that affect the competitive capacity of tourism in reservoirs, specifically in Hidrosogamoso; ii) influencing factors of tourism that contribute to local development, understood as a combination of economic growth and social welfare (Corzo \& Cuadra, 2019), so as to improve the local community's quality of life; and iii) guaranteeing tourism development in a way that respects the natural, cultural and social environment in which it unfolds, while also contributing to its preservation and regeneration.

Following this perspective and the previous analyses, a series of aims, objectives and strategies were identified with the aim of guiding the formulation of an environmental policy for tourism in the Topocoro reservoir. Pulido (2007) proposed a framework for the development of a tourism policy in natural parks, which has been taken as reference and adapted for the context of reservoirs.

\section{Aims}

The determination of aims (or final guidelines) corresponds to the public sphere. In this case, the Government of Santander is responsible for the aims of an environmental policy for tourism in the Topocoro reservoir. Given the purpose of this article, a series of aims have been identified to guide the environmental policy in this context:

1. Aiming for sustainability as the fundamental element of tourism development

2. Coordinating policy for tourism and territorial regulation

3. Integrating environmental resources as a first order element for tourist sites

4. Improving the financial capacity of the towns in the influence zone

5. Defining policy for efficient management of tourist flows

\section{Objectives}

General: Promoting tourism development in the Topocoro reservoir with a socioecological approach that contributes to preserving the natural and cultural patrimony, improving the local communities' quality of life, guaranteeing the educational use of nature, the visitors' and locals' environmental awareness, and promoting the essential principles of sustainability. Thus, nature tourism will become a competitive segment and the department will be strengthened as a tourist site.

Specific: Eleven specific objectives are proposed, each pertaining to one of the five aforementioned aims. These are:

Table 6. Specific objectives for the environmental policy for tourism

\begin{tabular}{|c|c|c|}
\hline Aim 1 & \multicolumn{2}{|c|}{$\begin{array}{l}\text { Aiming for sustainability as the fundamental } \\
\text { element of tourism development }\end{array}$} \\
\hline 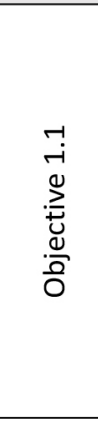 & $\begin{array}{l}\text { Promoting an } \\
\text { integral planning } \\
\text { of destinations in } \\
\text { the medium and } \\
\text { long term }\end{array}$ & $\begin{array}{ll}\text { i) } & \begin{array}{l}\text { Natural and cultural } \\
\text { patrimony of the }\end{array} \\
& \text { territory as a value } \\
& \text { proposition } \\
\text { ii) } & \text { Carrying capacity study } \\
\text { iii) } & \text { General objectives for } \\
& \text { quality } \\
\text { iv) } & \text { Analysis instruments } \\
\text { v) } & \text { Methods and systems } \\
& \text { for innovation } \\
\text { vi) } & \text { Financing } \\
\end{array}$ \\
\hline 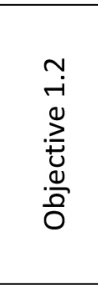 & $\begin{array}{l}\text { Ensuring the } \\
\text { adaptation of } \\
\text { methods and } \\
\text { technological } \\
\text { tools to each } \\
\text { territory's actual } \\
\text { situation }\end{array}$ & $\begin{array}{l}\text { Public budgets must consider } \\
\text { programs and guidelines with } \\
\text { explicit relation to the } \\
\text { sustainability objective }\end{array}$ \\
\hline 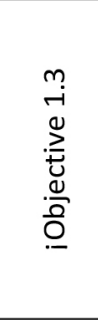 & $\begin{array}{l}\text { Providing } \\
\text { financial support } \\
\text { for micro and } \\
\text { small enterprises, } \\
\text { so as to } \\
\text { guarantee an } \\
\text { efficient use of } \\
\text { resources }\end{array}$ & $\begin{array}{l}\text { Public subsidies to facilitate } \\
\text { the incorporation of } \\
\text { sustainable production } \\
\text { processes in tourism } \\
\text { enterprises }\end{array}$ \\
\hline 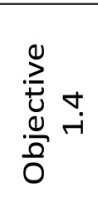 & $\begin{array}{l}\text { Promoting the } \\
\text { implementation } \\
\text { of sustainable } \\
\text { consumption } \\
\text { models }\end{array}$ & $\begin{array}{l}\text { Correctly informing tourism } \\
\text { consumers to positively } \\
\text { influence their behavior }\end{array}$ \\
\hline
\end{tabular}




\begin{tabular}{|c|c|c|}
\hline Aim 2 & \multicolumn{2}{|c|}{$\begin{array}{l}\text { Coordinating policy for tourism and territorial } \\
\text { regulation }\end{array}$} \\
\hline 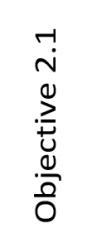 & $\begin{array}{l}\text { Setting limits on } \\
\text { land use for } \\
\text { tourism and living }\end{array}$ & $\begin{array}{l}\text { Territorial Regulation Plan } \\
\text { and Territorial Regulation } \\
\text { Framework }\end{array}$ \\
\hline 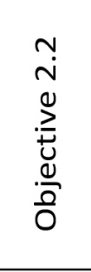 & $\begin{array}{l}\text { Reassessing } \\
\text { tourism } \\
\text { development } \\
\text { processed in } \\
\text { saturated spaces }\end{array}$ & $\begin{array}{l}\text { Restoring declining spaces } \\
\text { and reorganizing densely built } \\
\text { spaces can help preserve } \\
\text { local resources and revitalize } \\
\text { the authenticity of } \\
\text { destinations }\end{array}$ \\
\hline 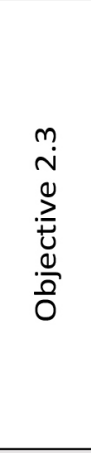 & $\begin{array}{l}\text { Placing special } \\
\text { care to } \\
\text { preserving } \\
\text { emerging } \\
\text { development } \\
\text { areas with } \\
\text { ecological, } \\
\text { patrimonial } \\
\text { and/or cultural } \\
\text { value }\end{array}$ & $\begin{array}{l}\text { Raising awareness among } \\
\text { public officials, companies } \\
\text { and local residents, in order } \\
\text { to plan according to the basic } \\
\text { principles of sustainable } \\
\text { tourism }\end{array}$ \\
\hline Aim 3 & \multicolumn{2}{|c|}{$\begin{array}{l}\text { Integrating environmental resources as a first } \\
\text { order element for tourist sites }\end{array}$} \\
\hline Aim 4 & \multicolumn{2}{|c|}{$\begin{array}{l}\text { Improving the financial capacity of the towns in } \\
\text { the influence zone }\end{array}$} \\
\hline Aim 5 & \multicolumn{2}{|c|}{$\begin{array}{l}\text { Defining policy for efficient management of tourist } \\
\text { flows }\end{array}$} \\
\hline 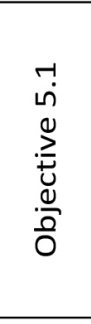 & $\begin{array}{l}\text { Determining the } \\
\text { conditions for } \\
\text { access to the } \\
\text { tourist } \\
\text { destination, or at } \\
\text { least to some of } \\
\text { its resources }\end{array}$ & $\begin{array}{l}\text { These conditions will } \\
\text { evidently depend on the } \\
\text { characteristics of each } \\
\text { territory and, more } \\
\text { concretely, to their carrying } \\
\text { capacity }\end{array}$ \\
\hline 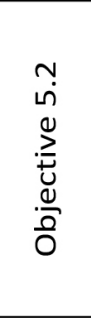 & $\begin{array}{l}\text { Selecting and } \\
\text { attracting market } \\
\text { segments that } \\
\text { may be ideal for } \\
\text { adequately } \\
\text { managing the } \\
\text { destination }\end{array}$ & $\begin{array}{l}\text { Great environmental and } \\
\text { cultural impact usually } \\
\text { originates from mass tourism }\end{array}$ \\
\hline
\end{tabular}

\begin{tabular}{|c|c|c|}
\hline 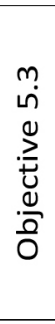 & $\begin{array}{l}\text { Distributing } \\
\text { tourist flows over } \\
\text { time }\end{array}$ & $\begin{array}{l}\text { Defining new strategies for } \\
\text { deseasonalizing demand- } \\
\text { since seasonal demand is } \\
\text { often more difficult to } \\
\text { manage-so as to facilitate } \\
\text { better distribution of tourist } \\
\text { flows over time }\end{array}$ \\
\hline 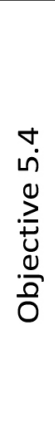 & $\begin{array}{l}\text { Distributing } \\
\text { tourist flows } \\
\text { across space }\end{array}$ & $\begin{array}{l}\text { Setting relief mechanisms in } \\
\text { the most visited areas and } \\
\text { preservation mechanisms in } \\
\text { the most fragile ones. This } \\
\text { should distribute tourist flows } \\
\text { towards less fragile areas } \\
\text { and/or areas with less } \\
\text { capacity, thus sequencing } \\
\text { visits to areas of greater use } \\
\text { or tourist intensity }\end{array}$ \\
\hline
\end{tabular}

Source: Author

This article has identified the main elements that should conform the environmental policy for tourism in the Topocoro reservoir, or any other reservoir with potential for tourism.

As a preamble to the study, a precise definition of sustainable tourism is offered, based on a socioecological principle that contemplates exploiting the tourist resource whilst preserving the environment and wellbeing of local communities. Furthermore, the challenges of generating an environmental policy for tourism are described, considering the exploitation-preservation dichotomy posed by sustainable tourism. The importance of the state as a regulating entity is stressed, with a mission to integrate the interests of the local community, the enterprises and the tourists. Through a participative process, this entity should create a policy for using the tourist resource in a way that preserves the natural environment and safeguards the integrity of local communities.

The study was developed as a document analysis, with a five-phase method: i) revising available literature, ii) classifying the documents, iii) selecting relevant sources, iv) reading and analysis, v) cross-analysis to compare the documents in question. This process derived in a socioeconomic analysis of the Topocoro reservoir, a competitive profile analysis that established a series of critical success factors for the development of tourism in reservoirs, and 
finally a set of guidelines for an environmental policy to regulate tourism.

The socioeconomic analysis provided a general view of the Topocoro reservoir, as the Sogamoso Hydroelectric Project is commonly known, with an influence zone distributed across five towns. The project was built and is managed by Isagén, a public-private enterprise conformed by the Colombian state together with private companies and some minor shareholders. It is the second largest hydropower plant in Colombia, with the capacity to produce $10 \%$ of the country's total energy requirement.

The environmental analysis reveals that the Topocoro reservoir has not been exempt of adverse effects on the environment due to poor initial management. As a response, the Reservoir Regulation Plan was created. However, other effects of tourism-a new phenomenon in the territoryexist that demand a similar policy for sustainable tourism.

The competitive analysis, based on a competitve profile matrix for the Guavio, Tominé, Guatapé and Topocoro reservoirs, warns of some risks associated with reservoirs that must be tended to. The predominant risks are pollution, floods, relocation of local community and changes in the productive dynamics of the territory.

The conclusion derived from these analyses is that the environmental policy for reservoir tourism should be oriented towards reinforcing competitive capacity, promoting local development and ensuring sustainable development of tourism. Thus, the environmental policy for reservoir tourism should aim for: i) sustainability, ii) coordinating policy for tourism and the territory, iii) integrating environmental resources, iv) improving the financial capacity of the towns in the influence zone, v) efficient management of tourist flows.

Under these principles, it is recommended that the environmental policy for sustainable tourism in the Topocoro reservoir adopt the preservation of the patrimony, the improvement of the community's quality of life, the educational use of nature and environmental awareness as general objectives. Following these guidelines will make it possible to turn nature tourism into a competitive segment and to make the reservoir territory more competitive as a tourist site.

\section{REFERENCES}

Ansar, A., Flyvbjerg, B., Budzier, A., \& Lunn, D. (2014). Should we build more largedams? The actual costs of hydropower megaproject development. Energy Policy, 69, 43-56

Ávila, R., \& Barrado, D. A. (2005). Nuevas tendencias en el desarrollo de destinos turísticos: marcos conceptuales y operativos para su planificación y gestión. Cuadernos de Turismo No. 15, 27-43.

Bertoni, M. (2008). Turismo sostenible: su interpretación y alcance operativo. Cuadernos de geografía: Revista Colombiana de geografía, (17), 155-163.

Coccossis, H. (1996). Tourism and sustainability: perspectives and implications. Sustainable tourism? European experiences., 1-21.

Corzo -Arévalo, D, \& Cuadra, Renzo. (2020). La integralidad del desarrollo territorial, un proceso entendido desde los conceptos: multiescalaridad, multisectorialidad y multidimensionalidad.

David, F. R. (2003). Conceptos de administración estratégica. Pearson Educación.

Díaz, J., Castaño, A., \& Navarrete, F. (2016). Impactos ambientales y sociales de la construcción de embalses en Colombia: Aproximación al estado del arte. Universidad la gran Colombia, Facultad de ingeniería civil.

Fortunato, N. (2019a). Contribuciones para el diseño de una Matriz de Evaluación de la Calidad de la Gestión Ambiental relacionada con el turismo. Universidad Nacional de Quilmes.

Fortunato, N. (2019b). Procesos Históricos y Política Ambiental del Turismo, Clase No. 1. Buenos Aires: Universidad Nacional de Quilmes. Maestría en Desarrollo y Gestión del Turismo.

Fortunato, N. (2019c). Procesos Históricos y Política Ambiental del Turismo, Clase No. 5. Buenos Aires: Universidad Nacional de Quilmes. Maestría en Desarrollo y Gestión del Turismo. 
Fuentes, H., \& Prada, S. (2017). Proyecto Estratégico Desarrollo Integral Embalse Topocoro. Bucaramanga: Gobernación de Santander. Secretaria de Planeación.

García Gonzales, L. (2004). Agua y Turismo. Nuevos usos de los recursos hídricos en la península ibérica. Enfoque integral. Boletín de la A.G.E. No. 37, 239-255.

García Lozano, C. F. (2017). Modelo de ocupación territorial sostenible para el área de influencia de la represa Topocoro sobre el río Sogamoso en Betulia Santander. Bucaramanga: Universidad de Santander UDES, Facultad de Derecho y Ciencias Políticas, Maestría en derecho para el urbanismo y desarrollo territorial sostenible.

ISAGEN. (2015). Embalse Topocoro. Formulación del Plan de Ordenamiento. Central Hidroeléctrica Sogamoso. Fundación Humedales. Bogotá.

Jaramillo Cortes, R. A. (2018). Costo económico de los impactos ambientales y el tamaño óptimo de los megaproyectos hidroeléctricos. Universidad $\mathrm{Na}$ cional de Colombia.

Kobal, E. (2002). Patrimonio ambiental y desarrollo sostenible. Revista Digital de Compilación sobre Temas Patrimoniales, Centro de Investigaciones y Estudios Turísticos (CIET), 21-29.

López, D. (1998). La ordenación y planificación integrada de los recursos territoriales turísticos,estudio práctico de un espacio de "desarrollo turístico incipiente": el Alto Palancia (Castellón). Universitat Jaume I.

Melgosa Arcos, F. J (1999). Turismo, medio ambiente y desarrollo sostenible. Estudios de Derecho y Ges- tión Ambiental (Tomo I).Fundación Cultural Santa Teresa y Junta de Castilla y León. 449 - 476.

Plata, V., \& Carlos, V. (2017). Incidencia de la hidropolítica en el Departamento de Santander, Caso: Represa Hidrosogamoso. Bucaramanga: 2do congreso internacional en administración de negocios internacionales. Universidad Pontificia Bolivariana.

Porto-Goncalves, C. W. (2009). De Saberes y de Territorios-diversidad y emancipación a partir de la experiencia latino-americana. Polis. Revista latinoamericana, (22).

Pulido Fernández, Juan Ignacio. (2007). Elementos para orientar la formulación de una política turística sostenible en los parques naturales andaluces. Cuadernos de Turismo, núm. 19.167-188

Reguero Oxinalde, M. (1994). Ecoturismo. Nuevas formas de turismo en el espacio rural. Barcelona: Bosch Turismo.

Roa, Tatiana. (2019). Hidrosogamoso: Discursos, conflictos y resistencias. Universidad Andina Simón Bolívar. Ecuador

Roa, T., \& Duarte, B. (2012). Aguas represadas. El caso del proyecto Hidrosogamoso en Colombia.

Swyngedouw, E. (2009). The political economy and political ecology of the hydro-social cycle. Journal of Contemporary Water Research \& Education, 142(1), 56-60.

Vera-Rebollo, J. F. (2001). Planificación y gestión del desarrollo turístico sostenible: propuestas para la creación de un sistema de indicadores. 